\section{Cost-Size Relationships of Utah Cattle Ranches ${ }^{1}$}

JOHN P. WORKMAN AND JACK F. HOOPER ${ }^{2}$

Assistant Professor, Range Resource Economics, Department of Range Science, Utah State University, Logan, Utah; and Vice-President, Armendaris Land Development Corporation, Kansas City, Missouri.

\section{Highlight}

Regression analyses of per cwt. beef production costs of four sizes of Utah cattle ranches indicate that no size of Utah range cattle operation up to 500 head is capable of covering all costs. When all production costs were taken into account, the 1968 optimum sized Utah cattle ranch from the ranch owner's viewpoint was 392 head of breeding cows. The weighted average beef price necessary for the optimum ranch size to meet all costs was $\$ 30.95$ per cwt. When interest on investment in land, livestock, and improvements was ignored, the optimum sized cattle ranch from the owner's viewpoint was one with a capacity of 414 breeding cows. In order to meet all costs except interest on investment, the optimum ranch size would require a weighted average beef price of $\$ 17.77$ per cwt.

Information concerning cattle ranch economies of size (phenomena which cause reductions in per unit costs as firm size increases) is important to potential investors in cattle ranch property and ranch owners interested in expansion. As pointed out by Faris and Armstrong (1963), cost-size relationships are of special concern to policy makers, as well as ranch operators. Both the formulation of efficient and equitable federal farm policy and sound ranch management depend upon knowledge of economies of size. In view of the need for cost economies information, a study was conducted in Utah beginning in 1967 to determine the cost-size relationships that exist in range cattle operations.

\section{Methods}

Investment, cost, and returns data for various sizes of Utah cattle ranches were obtained from rancher interviews and questionnaires throughout the state (Tables 1 and 2). The numerous observations were classified into four ranch

\footnotetext{
${ }^{1}$ Published with the approval of the Director, Utah Agricultural Experiment Station, as Journal Paper No. 1169. Reccived Junc 4, 1971.

${ }^{2}$ The rigorous review of the manuscript by colleague B. Delworth Gardner, Chairman, Dcpartmcnt of Economics, Utah State University, is gratefully acknowledged. The authors do, however, take full responsibility for any deficiencies of the paper.
}

groupings with average sizes of 50 , 150,300 , and 500 head of breeding cows. Data for the 50,150 , and 300 cow ranches wcre taken from a study by Roberts and Gee (1963) while figures for the 500 cow ranch These data allowed the identification of (1) cash costs, (2) costs of depreciation, (3) operator and family labor costs, and (4) the costs of interest on investment for each of the four ranch sizes (Table 3). Two long-run average cost (LRAC) curves were derived from these data by regression analysis. These curves show the functional relationship between per cwt. beef production costs and the quantity of beef produced annually. Simply stated, the "long-run" is viewed by economists as a time period of sufficient length for all inputs to be variable. This concept is one of convenience and even the longest of "long-runs" probably has some inputs held constant (an example is the management ability of the rancher). The distinction between the long-run and the short-run (the short-run is usually defined as a production period during which at least one input is fixed) is arbitrary by any standards. What is actually involved is a continuum ranging from the shortest to the longest conceivable production periods.

Two distinct points were located along the production period conwere collected by the authors. tinuum for the purpose of deriving two distinct LRAC curves. The first (LR $\left.\Lambda C_{1}\right)$ includes (1) cash costs, (2) depreciation, (3) opportunity costs of operator and family labor, and (4) interest on investment.

The second LRAC curve $\left(\mathrm{LRAC}_{2}\right)$ includes only (1) cash costs, (2) depreciation, and (3) the opportunity costs of operator and family labor. Interest on the rancher's investment in land, machinery, and improvements is excluded.

For the purpose of providing information to existing ranch operators or potential investors in beef production factors, it is probably more important to present both curves (letting the manager choose the one he considers relevant) than it is to attempt to justify one of the two as the correct curve. From the viewpoint of society, $\mathrm{LRAC}_{2}$ (which includes all costs including a normal return on investment) is the relevant curve. Even though private operators may ignore the opportunity costs of interest on investment, these are real costs that society cannot afford to ignore.

\section{Results and Discussion}

The regression equation for $\mathrm{LRAC}_{1}$ took the form

$$
\begin{aligned}
\mathrm{LRAC}_{1}= & 81.260-0.000569 \mathrm{P}+ \\
& 0.0000000016 \mathrm{P}^{2}
\end{aligned}
$$

where $\mathrm{P}=$ the pounds of beef produced. The $\mathrm{R}^{2}$ value was 0.89 and the t-values were significant at the 60 percent level for pounds and the 50 percent level for pounds squared. ${ }^{3}$ The graphical form of $\mathrm{LRAC}_{1}$ is shown in Figure 1.

The regression equation for $\mathrm{LRAC}_{2}$ took the form

$$
\begin{aligned}
\mathrm{LRAC}_{2}= & 60.501-0.000524 \mathrm{P}+ \\
& 0.0000000016 \mathrm{P}^{2}
\end{aligned}
$$

where $\mathrm{P}=$ the pounds of beef produced. The $\mathrm{R}^{2}$ value was 0.92 and

\footnotetext{
${ }^{3}$ The cost data taken from Roberts and Gee (1963) were published in pooled form. Thus, only four observations were available for each of the two regression analyses. This explains the low level of significance associated with the regression coefficients despite the impressive $\mathbf{R}^{2}$ values.
} 
Table 1. Summary of investment (dollars) for typical ranches, Utah, 1968.

\begin{tabular}{lrrrr}
\hline \hline \multirow{2}{*}{\multicolumn{4}{c}{ Item }} & \multicolumn{4}{c}{ Size of breeding herd } \\
\cline { 2 - 5 } & 50 & \multicolumn{1}{c}{150} & \multicolumn{1}{c}{300} & \multicolumn{1}{c}{500} \\
\hline Land & 40,500 & 72,250 & 148,250 & 218,100 \\
Federal grazing permits & 7,176 & 23,816 & 44,520 & 54,000 \\
Buildings and improvements & 7,300 & 16,865 & 30,160 & 53,620 \\
Machinery and equipment & 18,075 & 23,739 & 29,022 & 51,930 \\
Livestock & & & & \\
$\quad$ Cattle & 15,280 & 41,860 & 83,900 & 131,760 \\
$\quad$ Horses & 300 & 450 & 750 & 1,050 \\
Total investment & 88,581 & 178,980 & 336,602 & 510,460 \\
\hline
\end{tabular}

the t-values were significant at the 70 percent level for pounds and the 60 percent level for pounds squared. The graphical form of $\mathrm{LRAC}_{2}$ is shown in Figure 2.

\section{LRAC $_{1}$}

Long-run average costs $\left(\mathrm{LRAC}_{\mathbf{1}}\right)$ decrease as ranch size increases up to a ranch size of 421 head of breeding cows (Fig. I). These size economies are due to the intensification of cattle numbers on the cash costs of taxes and insurance causing these costs to be spread over more units of production. A related source of cost economies is the spreading of the implicit costs of depreciation, operator and family labor, and interest on investment. The cost diseconomies which exist as ranch size becomes larger than 421 head appear to be due primarily to the intensification of investment in machinery and equipment on cattle numbers (Tables 1 and 3).

Multiplying $\mathrm{LRAC}_{1}$ by $\mathrm{P}$ and taking the first derivative yields $\mathrm{LRMC}_{1}=81.260-0.001138 \mathrm{P}+$ $0.0000000048 \mathrm{P}^{2}$, which is long-run marginal cost (LRMC) expressed as a function of pounds of beef produced (Fig. 1). Setting the first derivative of $\mathrm{LRAC}_{1}$ equal to zero and solving for pounds gives the output corresponding to the minimum of $\mathrm{LRAC}_{1}$ and also to the output where $\mathrm{LRMC}_{1}=\mathrm{LRAC}_{1}$ $(177,812$ pounds or 421 head of breeding cows).

From the viewpoint of society (since it views efficiency in terms of quantity of output produced per unit of input) the optimum Utah ranch size is one capable of suptuting 421 head (177,812 pounds) into the equation for $\mathrm{LRAC}_{1}$ reveals that the price per cwt. of beef would have to be $\$ 30.67$ to cover all costs at the optimum cattle ranch size.

Imposing the 1968 weight average Utah price line of $\$ 24.00$ per porting 421 breeding cows. Substi-

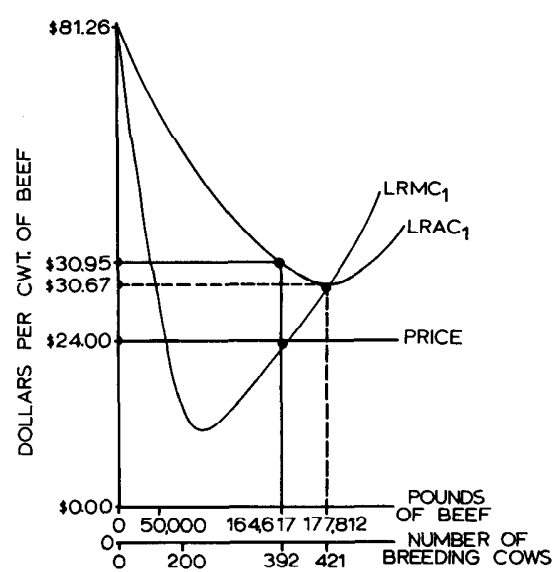

Fig. 1. Long-run average and marginal cost curves for beef production in Utah, 1968, when all costs are considered.

cwt. (Christensen and Richards, 1969) on the cost curves of Figure 1 , reveals that no size of Utah cattle ranch is capable of covering all costs of production at current prices.

Table 2. Production and sales of cattle ${ }^{1}$ of typical ranches, Utah, 1968.

\begin{tabular}{|c|c|c|c|c|c|}
\hline Ranch size & $\begin{array}{l}\text { No. } \\
\text { sold }\end{array}$ & $\begin{array}{c}\text { Average } \\
\text { weight (lb.) }\end{array}$ & $\begin{array}{c}\text { Iotal } \\
\text { weight } \\
\text { (cwt) }\end{array}$ & $\begin{array}{c}\text { Price } \\
(\$ / \mathrm{cwt})\end{array}$ & Value (\$) \\
\hline \multicolumn{6}{|l|}{50 breeding cows } \\
\hline cows & 7 & 1000 & 70 & 16.60 & 1162 \\
\hline heifer calves & 9 & 380 & 34 & 26.98 & 917 \\
\hline steer calves & 8 & 400 & 32 & 28.62 & 916 \\
\hline yearling steers & 12 & 600 & 72 & 24.00 & 1728 \\
\hline Total sales & & & 208 & 22.71 & 4723 \\
\hline \multicolumn{6}{|l|}{150 breeding cows } \\
\hline cows & 21 & 1000 & 210 & 16.60 & 3486 \\
\hline heifer calves & 35 & 380 & 133 & 26.98 & 3588 \\
\hline steer calves & 41 & 400 & 164 & 28.62 & 4694 \\
\hline yearling steers & 18 & 600 & 108 & 24.00 & 2592 \\
\hline Total sales & & & 615 & 23.35 & 14360 \\
\hline \multicolumn{6}{|l|}{300 breeding cows } \\
\hline cows & 34 & 1000 & 340 & 16.60 & 5362 \\
\hline heifer calves & 73 & 380 & 277 & 26.98 & 7473 \\
\hline steer calves & 85 & 400 & 340 & 28.62 & 9731 \\
\hline yearling steers & 37 & 600 & 222 & 24.00 & 5328 \\
\hline Total sales & & & 1179 & 24.01 & 27894 \\
\hline \multicolumn{6}{|l|}{500 breeding cows } \\
\hline cows & 50 & 1000 & 500 & 16.60 & 8300 \\
\hline heifer calves & 171 & 380 & 650 & 26.98 & 17537 \\
\hline steer calves & 175 & 400 & 700 & 28.62 & 20034 \\
\hline yearling steers & 50 & 600 & 300 & 24.00 & 7200 \\
\hline Total sales & & & 2150 & 24.68 & 53071 \\
\hline
\end{tabular}

${ }_{1}^{1}$ Bulls are treated as capital items and accounted for in depreciation. 
Table 3. Total and average (per cwt. beef) costs of beef production on typical ranches, Utah, 1968 (dollars).

\begin{tabular}{|c|c|c|c|c|}
\hline \multirow[b]{2}{*}{ Item } & \multicolumn{4}{|c|}{ Size of breeding herd } \\
\hline & 50 & 150 & 300 & 500 \\
\hline \multicolumn{5}{|l|}{ Cash Costs } \\
\hline \multicolumn{5}{|l|}{ Grazing fees } \\
\hline BLM & 88 & 365 & 771 & 825 \\
\hline FS & 131 & 350 & 545 & 792 \\
\hline Labor hired & 150 & 360 & 3200 & 6600 \\
\hline Feed purchased & 161 & 307 & 2244 & 1100 \\
\hline \multicolumn{5}{|l|}{ Repairs and maintenance } \\
\hline Buildings and improvements & 175 & 458 & 831 & 1200 \\
\hline Machinery and equipment & 922 & 1074 & 1541 & 2062 \\
\hline Veterinary services and supplies & 41 & 59 & 439 & 500 \\
\hline Taxes & 719 & 1351 & 2616 & 2900 \\
\hline Seed and fertilizer & 236 & 590 & 1210 & 1322 \\
\hline Machine operating costs & 625 & 1294 & 1659 & 2500 \\
\hline Machine hire & 207 & 309 & 620 & 750 \\
\hline Insurance & 101 & 133 & 133 & 200 \\
\hline Utilities & 41 & 283 & 400 & 500 \\
\hline Irrigation water & 224 & 389 & 873 & 1200 \\
\hline Miscellaneous & 345 & 476 & 637 & 850 \\
\hline Interest on cash costs & 166 & 312 & 664 & 932 \\
\hline Total cash costs & 4332 & 8110 & 18383 & 24233 \\
\hline Total cash costs-value crops sold & 2782 & 6631 & 14664 & 24233 \\
\hline Average cash costs (per cwt. beef) & 13.37 & 10.78 & 12.44 & 11.27 \\
\hline \multicolumn{5}{|l|}{ Non-Cash Costs } \\
\hline \multicolumn{5}{|l|}{ Depreciation } \\
\hline Buildings and improvements & 365 & 813 & 1508 & 2681 \\
\hline Machinery and equipment & 2892 & 3798 & 5044 & 8309 \\
\hline Bulls & 120 & 460 & 1150 & 1918 \\
\hline Horses & 30 & 45 & 75 & 105 \\
\hline Total operating costs & 6189 & 11777 & 22441 & 37246 \\
\hline Average operating costs & 29.75 & 19.15 & 19.03 & 17.32 \\
\hline Operator and family labor & 1800 & 6000 & 8000 & 9600 \\
\hline Total operating and labor costs & 10989 & 17777 & 30441 & 46845 \\
\hline Average operating and labor costs & 52.83 & 28.90 & 24.82 & 21.79 \\
\hline Interest on investment $(5 \%)$ & 3847 & 7960 & 15244 & 22715 \\
\hline Total operating and opportunity costs & 14836 & 25737 & 45685 & 69560 \\
\hline Average operating and opportunity costs & 71.33 & 41.85 & 38.75 & 32.35 \\
\hline
\end{tabular}

The tendency for Utah cattle ranchers to remain in business despite the net losses which all ranch sizes are experiencing may be explained by ccrtain costs included in the curves of Figure 1 not being viewed as real costs by ranchers. An example of such an item is the opportunity cost of interest on investment. Another possible explanation is that other values derived from the ranching business such as the "way of life," tax advantages, and land appreciation move the effective price line (as subjectively

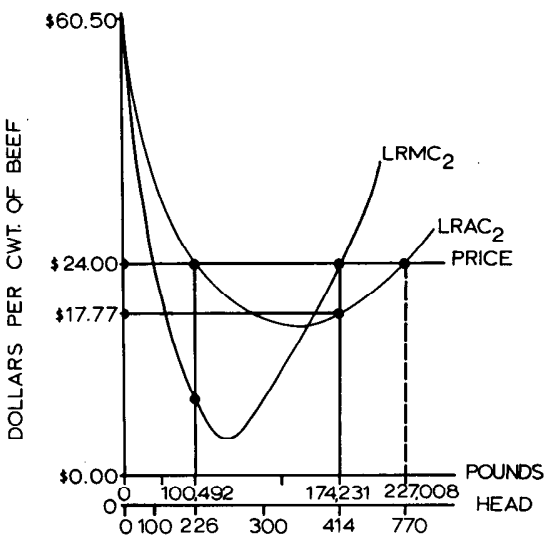

Fig. 2. Long-run average and marginal cost curves for beef production in Utah, 1968, when interest on investment is ignored.

costs at the rancher's optimum cattle ranch size is $\$ 30.95$ per cwt.

\section{LRAC $_{2}$}

Since no size of Utah cattle ranch is capable of covering all long-run costs, regression analysis was used to generate a second LRAC equation $\left(\mathrm{LRAC}_{2}\right)$. This equation expresses the average of all costs except interest on investment (which the rancher may not view as a real cost) as a function of pounds of beef output. Long-run average costs decrease up to a ranch size of 390 head of breeding cows and then increase (Fig. 2). Explanation of the cost economies and diseconomies follows that given for $\mathrm{LRAC}_{1}$.

Multiplying $\mathrm{LRAC}_{2}$ by $\mathbf{P}$ and taking the first derivative gives

$$
\begin{aligned}
\mathrm{LRMC}_{2}= & 60.501-0.001048 \mathrm{P}+ \\
& 0.0000000048 \mathrm{P}^{2},
\end{aligned}
$$

which is the equation for long-run marginal cost when interest on investment is ignored. $\mathrm{LRMC}_{2}$ appears in graphical form in Figure 2.

The optimum ranch size from the ranch owner's viewpoint (when interest on investment is ignored) is 414 head of breeding cows (Fig. 2). This output is determined by setting $\mathrm{LRMC}_{2}$ equal to the 1968 Utah weighted average price $(\$ 24.00)$ and solving for pounds of beef. The beef price necessary to pay all costs for the ranch owner's optimum ranch size is $\$ 17.77$ per cwt. This value is found by sub- 
stituting 174,231 pounds into the equation for $\mathrm{LRAC}_{2}{ }^{4}$

By setting $\mathrm{LRAC}_{2}$ equal to price and solving for pounds, it can be shown that a ranch supporting 226 head is the minimum size necessary to cover all costs (except interest on investment) at the 1968 weighted average beef price of $\$ 24$ per cwt. The maximum cattle ranch size which yields positive returns, as shown in Figure 2, is 770 head. However, this 770 head figure represents a functional extrapolation. Data were available for cattle ranch sizes up to 500 head and for much larger ranches supporting 7500 head or more. In 1968, few ranch sizes existed in Utah between 500 and 7500 head of cattle. This in itself may be a commentary on cost economies of size and investment strategy. Perhaps cattle ranches with a capacity of 500 head or less are

${ }^{4}$ It should be noted that from the viewpoint of society, the optimum ranch size is still that capable of supporting 421 head (Fig. 1) since LRAC 1 (which includes all costs) is the relevant curve in terms of social costs. "family" ranches which manage to remain in business by ignoring the costs of family labor and interest on investment. Ranches larger than 500 head may be run by sophisticated investors seeking tax shelter and long term capital gain.

\section{Summary and Conclusions}

Analysis of long-run average and marginal cost curves derived from regression of data from four sizes of Utah cattle ranches revealed that no size of range cattle operation up to 500 head is capable of covering all costs. If all costs of production are taken into account, the optimum Utah cattle ranch sizes are 421 head from society's viewpoint and 392 head from the rancher's viewpoint. The weighted average beef prices necessary to cover all costs at these optima are $\$ 30.67$ and $\$ 30.95$ per cwt., respectively.

The data were also subjected to analysis under the assumption that ranch owners do not view interest on investment as a real cost. When interest on investment is dropped from the analysis, the resulting long-run average and marginal cost curves show that the optimum ranch size from the owner's point of view is one capable of supporting 414 head. The beef price necessary to cover all costs (except interest on investment) at this output is $\$ 17.77$ per cwt. The minimum size of cattle ranch capable of paying all costs (except interest on investment) is 226 head in terms of 1968 prices.

\section{Literature Cited}

Christensen, R. A., and S. H. RichARDS. 1969. Price trends for decision making in agriculture. Utah, 1969. Utah Agr. Exp. Sta. Resource Series 49. $83 \mathrm{p}$.

Faris, J. E., and D. L. Armstrong. 1963. Economies associated with size, Kern County cash-crop farms. Giannini Foundation Res. Report 269. $121 \mathrm{p}$.

Martin, W. M., and W. K. Goss. 1963. Cost-size relationships for southwestern Arizona cattle ranches. Ariz. Agr. Exp. Sta. Tech. Bull. 155. 38 p.

Robrrts, K. N., and C. K. Gef. 1963. Cattle ranches using public ranges year-long. Utah Agr. Exp. Bull. 440. $21 \mathrm{p}$. 